\title{
Food Heritage and \\ Nationalism in Europe
}

\section{Edited by llaria Porciani}

First published 2019

ISBN: 978-0-367-234I 5-7 (hbk)

ISBN: 978-0-429-27975-I (ebk)

Chapter I

Food heritage and nationalism in Europe

Ilaria Porciani

(CC BY-NC-ND 4.0)

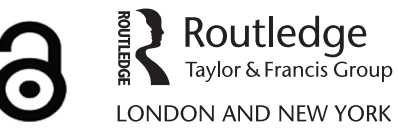




\title{
Food heritage and nationalism in Europe
}

\author{
Ilaria Porciani
}

\section{Food: heritage for uncertain times}

More than ever, food occupies a central place in our thoughts and our imagination. The less we cook or eat in a decent way, the more we are concerned with the meaning and strategies of cooking, the authenticity of recipes and their normative grammar. Food, the most accessible threshold of culture (La Cecla 1997), is ubiquitous in television series and programmes, films (Saillard 2010), magazines, newspaper articles and novels (Biasin 1991; Ott 2011), as well as in recent and very popular detective stories. Commissario Montalbano, created by Andrea Camilleri, makes a point of praising the true Sicilian cooking of his housekeeper while despising the cuisine from distant, albeit Mediterranean, Liguria as prepared by his fiancée. The hero of Petros Markaris's detective novels, Inspector Costas Charitos, a Rum - that is, a Greek born in Istanbul - explores contact zones and frictions between the often overlapping cuisines of the two communities. The detective created by Manuel Vásquez Montálban constantly describes local and national dishes from his country in vivid detail, and mirrors the tension between local, Catalan and national cuisine. Why should this be so if these attitudes did not speak immediately to everyone?

In every culture, "foodways constitute an organized system, a language that through its structure and components - conveys meaning and contributes to the organization of the natural and social world" (Counihan 1999, 19). Worldwide, as well as across social classes and different milieus, food conveys feelings of community and inclusion. Food reminds us of the protective intimacy of the private home and the national home at one and the same time. Besides being a powerful means of integration within a group for some, it enables recognition within a taxonomic classification (Fischler 1988). Yet it can also effectively voice "othering" and disgust for others. Thus the emotional connection between food and the feeling of national belonging is also used and misused by politicians in various countries to mobilize the masses.

In times of presentism (Hartog 2015), heritage-making is a response to anxieties about malbouffe - fast food, bad food and bad eating habits (Binet 2016) - "MacDonaldization", the consequences of extreme industrial food 
manufacturing and the fear of globalization and mass immigration. The need to create food heritage is partly the result of a longing for grandmothers' "authentic" cuisine, with its supposedly deep roots in our traditions, which are meant to be rediscovered and protected. Edible chronotopes (KirshenblattGimblett 2004, xiii) contain and embody the memory of people and places through time and space. When food is designated as heritage it "takes on even greater emotional weight" (Brulotte and Di Giovine 2014, 2).

These fantasies are often entangled with the nostalgia (Boym 2001; Duruz 1999; Renko and Bucar 2014; but also Holak 2014; Holtzman 2006, 367-8; Mannur 2007) characteristic of the most extreme cases of contemporary nationalism. Often it is nostalgia for a rural "countryside-nation" such as is proposed in open-air museums (Skansen in Norway or Beamish in the United Kingdom being two good examples) or in the English television heritage series devoted to Avis Crocomb, which attracted not fewer than 12 million viewers online alone. The chief cook of Lord and Lady Braybrooke at Audley End House in the Victorian age is shown picking fresh fruit from a very English orchard, or preparing English breakfast in the authentic castle's historical kitchen. A wave of nostalgia for the rural past was evident in Japan as well (Cwierta 2006).

While our society becomes liquid (Baumann 2000) and our world is characterized by a "global ethnoscape" (Appadurai 1996) largely deterritorialized and marked by a new irrelevance of space, we are drawn to imagine food in terms of authenticity, tradition and terroir - a French word which designates a rather small terrain "whose soil and microclimate impart distinctive qualities to food products" (Barham 2003, 131; Demossier 2016; Saillard 2010). Because we are losing contact with things and practices which used to be alive and familiar, we turn them into heritage (Nora 1989). This trend is by no means confined to food: heritagization is a much wider phenomenon in almost all countries Europe being probably at the forefront.

Closely connected to this context is the "heritage vegetable discourse" centred on guardianship. Its linear narrative presents the past "not only as better, freer and more diverse, but also unchanging", and emphasizes a continuity with past generations, which may be "a matter of centuries as in the documents issued by the British National Trust, millennia or even prehistory as in the Science and Advice for Scottish Agricultural Website" (Wincott 2015, 577-8). Abigail Wincott classifies the British organizations involved under the following broad categories: "heritage conservation bodies (such as the National Trust and the Heritage Seed Library), activist groups (for example Reclaim the Fields), lifestyle journalists and experts, seed catalogues and garden centres, those selling heritage vegetables and fruit as luxury or premium food (these include restaurants and supermarkets, selling heritage vegetables in their luxury food ranges) and academics studying traditional crops". The mapping of the field of actors - she points out - "is successful in giving an indication of how broad the range of activities is, stretching from anticapitalist agitation to fine-dining and it throws up some interesting questions about the role of mainstreaming and 
different models of funding" (Wincott 2015, 574-5). Although related only to the United Kingdom, this picture mirrors the variety of subjects and agencies involved in the process of heritagization.

In being turned into heritage, food becomes part of a transaction. Like every other kind of heritage understood as such, it is the object of a pact (or unspoken contract) between those who confer heritage status on it and the people. In the 19th and 20th centuries the blueprint of this quite informal pact "profoundly linked to nation-building" (Adell, Bendix, Bortolotto and Tauschek 2016, 7) was written by national intellectuals and folklorists engaged in researching the national traditions of the people, and producing the nationalpopular master narrative in order to promote what they called the national "awakening". Ministries and public bodies of newer or older nation states and also supranational institutions contributed further, and so did many cooks and middle-class housewives, aristocrats and gourmets who volunteered to participate in the informal task of creating a culinary identity for the nation.

In recent times, new tools have been created to "enhance and protect the legal, commercial and cultural values of foods and customs whose characteristics and reputation can be variously attributed to their origin" (Parasecoli 2017, 2). On one hand are place-based labels such as Protected Designation of Origin (PDO) as well as the broader category of Geographical Indication (GI); on the other hand is UNESCO's list of Intangible Cultural Heritage (ICH). UNESCO mentioned intangible cultural heritage in its 1989 Recommendation for the Safeguarding of Traditional Culture Folklore. However, it was not until 2003 that UNESCO's Convention for the Safeguarding of the Intangible Cultural Heritage was passed, and only from 2010 was food included (Clough 2015; Di Fiore 2018a).

More than ever this process of heritagization of food (as of other "things" and tangible or intangible practices) is characterized by the logic of cultural engineering based on nation states (Adell et al. 2016; Hannerz 2006, 79; Kuutma 2012, 30) and can lead to ambiguities and shortcomings (Hertz 2017). It is governed by a nomos and enters a complex system of negotiations. While free intellectuals are still vocal about the topic, it is public bodies that are appointed as culinary or food quality authorities. In this case the pact becomes more complicated and its effect more coercive. The official grammar triumphs over vernacular languages and dialects, and hierarchies are constructed. Some foods are included; others are necessarily excluded. French scholars have reflected on surclassement patrimonial - that is, the effect of skating over a great variety of possible heritage while projecting a highly selective light of heritage only on a few things or practices. The picture becomes complicated and conflictual, because authorized heritage discourse - be it local, national, multinational or supranational - privileges some actors while disengaging others from the active use of heritage (Smith 2006).

Food heritage reconfigures relations of power and meaning as well as practices, and has an immediate impact on production, consumers and commodities: in 
short, on the market. Put succinctly, heritage becomes one arena of cultural propertization (Bendix, Eggert and Peselmann 2012). Moreover, it brings about a new way of constructing a narrative about what has been recognized as heritage (Fox 2007, 554). This happens in the case of geographical quality indications as well as in UNESCO's list of intangible heritage. In both cases, competitive confrontation among states or regions - originally probably unintended - is in reality a major result of these procedures. Moreover, food is part of the important recent process of commercializing memory cultures (Narvselius 2015, 417): the market amplifies constructed memories and traditions and makes intensive use of often simplified and invented culinary traditions.

Discussing food heritage implies navigating between operational definitions (principally UNESCO's) and the scholarly ones, including the definition suggested by Christopher Whitehead, Gönül Bozoğlu and Mads Daugbjerg (2019): heritage is "a representational, discursive and performative practice involving conscious attempts to symbolically valorize aspects of the past in the present". This prompts useful considerations. First of all, it brings to light how difficult it is to define heritage, and how senses of heritage have changed over time. Secondly, it sheds light on the implicit or explicit political intentions behind inventories and norms of protection, but also the accurate definition of the specific qualities needed in order to consider a practice as part of patrimoine. Thirdly, it helps to better understanding what David Lowenthal already pointed out many years ago: heritage "distinguishes us from others. It gets passed only to descendants, to our own flesh and blood; newcomers, outsiders, foreigners all erode and debase it" (Lowenthal 1994, 47). Working on the complexity of food as heritage can help to deconstruct such assumptions showing entanglements and overlaps, as well as highlighting shared practices among many people in Europe and sometimes across the Mediterranean.

The long-term perspective of most of the chapters of this book will help to focus on how these perspectives have changed from the long 19th century - the century of nationalisms, when heritage was inextricably connected to nations to recent steps aiming to establish certain foods as world intangible heritage. Moreover, the double nature of food as a material "thing" made of ingredients and as a long-lasting but also perpetually evolving practice complicates the picture. As Laura Di Fiore explains in Chapter 2 of this volume, the UNESCO 1972 definition of heritage at first did not accommodate food as heritage: food came later, and not without problems.

In order to shed light on those issues, the first section of this book deals with the political issue of food in processes of heritagization (Di Fiore, Chapter 2) and labelling (Parasecoli, Chapter 3), within market strategies (Capuzzo, Chapter 4), in politically oriented movements (Tolomelli, Chapter 5) and in museums (Eckersley, Chapter 6). Part II of this book tries to explain why it is difficult to consider food as "original national heritage", because of the many exchanges and grafting processes over a long period, though more specifically since the Middle Ages (Montanari, Chapter 7) and in the subsequent 
empires (Horel, Chapter 8; Samanc1, Chapter 9). It also focuses on the 19th and early 20 th centuries by drawing attention to restaurants in different global contexts: the Universal Exhibitions (Williot, Chapter 10) and global trade (Knyazeva, Chapter 11).

\section{Food heritage and nationalism: state of the art}

In the 1980s nationalism and food studies started to be identified as precise scholarly fields. However, due to the existing disciplinary borders they proceeded in parallel. In the 1980s heritage studies too was established as a specific discipline, but it took some time before it turned towards the topic of food (Poulot 2015). Until a few years ago, cross-fertilization was limited. One important exception was Nora's seminal Lieux de mémoire, where a chapter on gastronomy and one on wine (Durand 1992; Ory 1992) figured prominently among the traditions of the nation. For France, it would probably be impossible to omit either of them, both for the role of gastronomy in nation-building and for the early interest in the topic of food shown by French historiography (Flandrin 1992, 1999, 2000; Pilcher 2012, 44; Rowley 1997, 2006; Watts 2012).

Hobsbawm focused on the invention of tradition and on nationalism (Hobsbawm 1983, 1990), but failed to mention food, and so did Ernst Gellner (1983) and many others, including those authors who focused on nationhood from below, or on the gendered nature of nation-building processes (Blom, Hagemann and Hall 2000). Food is quoted only twice (and not in connection with its symbolic power) in Billig's Banal Nationalism (Billig 1995).

While in 2004 Ben Rogers still lamented that historians and sociologists had not taken much interest in nationalism of the culinary kind (Rogers 2004), the picture has changed in the past few years. Building on the earlier works of Claude Lévi-Strauss (1958), Mary Douglas (1966) and Roland Barthes (1961), recent scholars have highlighted that food-related practices can be read as signifying systems whose meanings are determined by the cultural context. It has become clear that "in every culture, food-ways constitute an organized system, a language that - through its structure and components - conveys meaning and contributes to the organization of the natural and social world" (Counihan 1999, 19; Counihan and Kaplan 1998). Historians (Scholliers 2001) and anthropologists have discussed the symbolic significance of food in the construction of national self-identity (Ohnuki-Tierney 1993).

In recent years, however, as part of a new attention to banal nationalism, scholars have started to investigate the role of food in the perception and construction of the nation. With the help of historians, anthropologists, sociologists and heritage scholars, research on food heritage and nationalism has grown immensely (Di Fiore 2018b). Bessière (2001) describes food heritage as a set of material and immaterial features in a community's food culture that have become recognized as a common good: a broad set, not excluding innovation (Bessière 2010; Bessière and Tibère 2010) and including foods and recipes, 
kitchen utensils or ways of eating together and even of setting the table. This is not without its significance: many national museums have found room for table-laying, a crucial point of middle- and lower-class domestic life and upperclass ostentation.

Some scholars (Ramli, Zahari, Ishahk and Sharif 2013) have concentrated on how food heritagization has tied up with the tradition of foods prepared and consumed over an unbroken sequence of generations. As one reads them, though, the doubt immediately arises that in many cases these traditions may not have been so continuous, and that some invention and reinvention may have taken place (Hobsbawm and Ranger 1983; Holtzman 2006). Others have tried to divide the gastronomic heritage into two categories: foods that form part of everyday life and foodstuffs that are disappearing or have already disappeared. The memory of a food may linger even after it has vanished, and may go on fuelling nostalgia, as some folklorists intuited many years back (Evans 1942, 73).

Parkhurst Ferguson (2010) reflected on culinary nationalism and De Soucey even coined the term gastronationalism (de Soucey 2010). Scholars have started investigating culinary politics and its role in the consolidation and transformation of nation states, as in Japan (Ichijo and Ranta 2016); they have highlighted how important those policies were in consolidating community ties and affirming strong political identities (Gvion 2011). Aykan speaks of a new "food heritage fever" (Aykan 2016, 799) while Demossier has investigated the role of terroir (Delfosse 1997, 2011; Demossier 2016), which had become a clear issue even in French state banquets during Chirac's presidency (Roux 2017): in fact, nowhere is the symbolic meaning of food more in evidence than at public events. Julia Csergo wrote of her own experience as a scholar in charge of the UNESCO candidature of the gastronomic meal of the French (Csergo 2016; Tornatore 2012). The debate on the politics of protected and controlled GIs and the complexities of labelling lead on to global issues, as Parasecoli also shows in this book. And it is on a global scale that the issue of immaterial heritage has arisen, as proposed by UNESCO ever since developing countries and the Global South and North began pressing for broader, more inclusive definitions of heritage, taking account of what they perceive as heritage, as against Eurocentric standards. Laura Di Fiore explains this well in her chapter for this book.

Old as well as recent hostilities between countries have often fuelled food wars, and clearly impact UNESCO applications. As Ubertazzi $(2015,114)$ has pointed out, "in certain cases, the proposal of these multinational nominations proves impossible for example, when the same states concerned are at war with each other, or are experiencing bad relations for whatever reason." This is the case with kimchi (Han 2011), the candidature for which described it as an essential part of the Korean way of life. ${ }^{1}$ Historians have also followed the disputes between Indonesians and Malese (Chong 2012).

Scholars, increasingly interested in conflicts, have followed and interpreted recent food wars, starting from the one between Greeks and Romanians about sarma or feta cheese (Mihăilescu 2012) and between Greek Cypriots, Turks and 
Cypriots, based on the contested UNESCO nomination of Lokoumi (Welz 2013). They have analysed the war over the property of falafel contested between Palestine and Israel (Raviv 2003), or over hummus among Israelis, Palestinians and Lebanese (Ariel 2012), all increasingly relevant to UNESCO nominations to $\mathrm{ICH}$.

In 2017 a new food heritage war between Israeli and Palestinians crystallized around zatar: Palestinians wish to repeat ancient rituals and get together to gather it, while Israeli authorities are trying to protect this herb, probably mentioned in the Bible and in danger of extinction. Haaretz pointed out that this war has been going on since 1977, when environmentalists succeeded in transforming the list of 257 protected species into law. The Palestinian Heirloom Society was also set up to protect something belonging intimately to Palestinian identity. Once more, the struggle is both an identity and a commercial battle, while top chefs use the herb to create internationally successful dishes (Frattini 2017).

The case of the protest against the label "Palestinian salad" on a dish with a couscous base, offered by Virgin Atlantic Airlines (which was apparently forced to change the name to "couscous salad") is a good instance of how the reference to a regional or typical dish in an attempt to be commercially attractive can turn into a disaster. But even more interesting is the airline's reply: "Maftoul is Palestinian, just like pasties are Cornish and pâté de foi gras is French." But are we sure that the French can claim foie gras as a national dish, when precisely this dish has a distinct pre-national origin in Jewish cuisine? Food historians know very well that duck was notoriously the Jews' pork, and back in the 16th century Bartolomeo Scappi or Marx Rumpolt recommended preparing foie gras from the liver of ducks raised by Jews in various areas, especially Bohemia (Toaff 2004,275-81). This is a clear example of how a dish may become "nationalized" when its long diaspora history, characterized by mediation and hybridism, is neglected.

\section{Food and national branding: gastrodiplomacy}

"[Catalonia] is not an invention: there is a territory, a community, a language, a culture and, in my case, a cuisine. Thus, my friends, this is a nation" (quoted in Pujol 2009, 438). In 2006 chef Carme Ruscalleda openly supported Catalan nationalism through gastronomy with this strong statement. The new use of food in national narratives with different aims - as diverse as encouragement of devolution, or promotion of the national brand - has become so important that the old term of culinary diplomacy, still used by some scholars (ChappleSokol 2013), has often been supplanted by a neologism: gastrodiplomacy. This new concept refers to actions taken by governmental, private and public agencies in order to use "soft power - the power of attraction", and to promote "the art of winning hearts and minds through stomachs" (Rockower 2012, 1). Gastrodiplomacy has been, for instance, at the core of aggressive tourist policies, such as the official Global Thai Program launched in 2002 in order to erase 
Thailand's previous image as a destination for sex tourism. Recipes, restaurant décor, staff dress and atmosphere were carefully planned to sell exoticism rooted in traditional national cooking. And yet, as we see in the conclusions of this book, this cuisine was to some extent trivialized and standardized in order to accommodate the taste of international tourists. Numbers are relevant. With 25 million tourists in 2014, Thailand's success was so evident that this model was soon imitated by Taiwan (Chen 2011), South Korea and Peru (Ranta 2015, 36-8). Malaysia has also tried to tailor its national gastronomic identity in order to attract and retain its almost 26 million tourists (Omar, Karim, Bakar and Omar 2015). Many similar cases of gastrodiplomacy aim at developing tourism (Alonso and Krajsic 2013; Cohen and Avieli 2004; Gössling and Hall 2013; Harrington and Ottenbacher 2010; Sims 2009; Timothy 2016).

In Europe these policies have often combined food with history and cultural heritage. In 2005-2006 the Generalitat of Catalonia organized "L'any del manjar, cuina i gastronomia" (The Year of Food, Cuisine and Gastronomy) "to commemorate 600 years of gastronomical culture through lavish exhibits and multitudinous talks by chefs, who had already become media superstars" (Pujol 2009). In 2016 the Italian conference on Soft Power, Made in Italy and Italian Lifestyle in the World had the aim of promoting the country's image, remembering its cuisine and "not just exploiting the sector's economic potential, but trying to give due worth to that immaterial heritage of traditions and artisan expertise that may prompt foreign public opinion to reappraise Italy's role in the world". 2

A good case in point in linking marketing, branding and national cultural identity is the New Nordic Cuisine (NNC), launched in 2004 by a group of chefs. New Nordic Cuisine is trying to create a new terroir for the Nordic identity (Tholstrup Hermansen 2012), in order to challenge French hegemony over haute cuisine. It defines culinary excellence as based only on products grown in the north, which are marketed as expressing the purity, freshness, simplicity and ethics associated with the region (Haraldsdóttir and Gunnarsdóttir 2014). However, there is no real agreement on what Nordic cuisine actually means because blatant tensions have arisen between Denmark and Norway. According to Neuman and Leer (2018), Danish texts actually refer to a shared Nordic culinary identity, whereas this is the case in only 5 out of 51 (approximately $10 \%$ ) of the Swedish texts in their sample. Qualitative analysis too reveals that Nordic cuisine is for the Danes almost interchangeably connected to Danish cuisine, while in Sweden NNC's culinary excellence is construed as specifically Swedish (Neuman and Leer 2018). New Nordic Cuisine, whose flagship was the Noma restaurant in Copenhagen, was heavily financed by Denmark to the tune of no less than 25 million DKK. However, the project has its cultural side: it will develop a foundation for a future Nordic knowledge centre linking not only Sweden and Denmark, but Greenland, Norway, Iceland, the Faroe Islands and Finland as well. 
A few years before NNC was created, Denmark developed another kind of memorialization, linking national foundation myths with the need to rescue national eating habits. On 7 June 2000, the Danish Potato Council proposed in a press release to designate Valdemar's Day as Danish National Potato Day (Gold 2007, 115). Valdemar's Day - a highly respected national holiday commemorates Dannebrog, the mythical Danish flag which flew from the sky in 1219 during a battle in Estonia.

Promotion of national food in connection with national identity and rivalry on an international scale also prompted Emmanuel Macron's proposal to include the baguette in UNESCO's ICH. Explicitly presented as a reaction to the inclusion of the art of the Neapolitan pizzaiuolo, this proposal was also suggested by other impellent needs in France's political scene. Moving away from haute cuisine, it provided the opportunity to highlight the "everyday" of all French people: one single national food that could unite a country lacerated by the issue of the veil and laicité, while also going beyond specifically regional and local concerns. ${ }^{3}$

\section{Populisms and mixophobia}

Food can mirror mixophobie: the fear not just of foreignness and otherness, but of mestization. Anthropologists know well that "people who eat strikingly different foods or similar foods in different ways" might be thought to be "strikingly different, sometimes even less human" (Mintz 1985, 3). The subject is important for the way populist movements (Kaya 2019) have used the food issue. To ridicule others for their food is no new strategy: it is found in the age of early nationalism and colonialism. In recent years some European populist movements have made great play with it against migrants and Muslims. This broadly transversal phenomenon deserves attention for all its implications, such as potential leverage over a medium-low culture public and its marked communicative relevance. Significantly, both Lega Nord, who started the trend, and Alternative für Deutschland (AfD) have used food for some of their most successful electoral posters.

"Yes to polenta - No to couscous" was one of the Lega's top slogans of the 1990s (McKinley 2010). More recently the AfD used a picture of young women in classic Bavarian costume - the dirndl - to convey the message: "Trau dich, Deutschland. Burka? Ich stehe mehr auf Burgunder" (Germany, take my word for it. Burka? I prefer Burgundy wine). France followed with a slogan combining nostalgia for terroir and islamophobia in the slogan devised by Nissa Rebela in Nice (Binet 2016, 241): "Non au kebab, oui à la socca" (no to kebab, yes to socca). Incidentally, socca is not a French food: this thin, unleavened chickpea pancake is no different from the cecina eaten in Pisa or the farinata that probably originated from Genoa, but is also present in many seaports in Italy such as Livorno (where it is again called cecina) or in Palermo (panelle). Thus 
socca is not an identity marker for Provence, but quite possibly a typical food of the Mediterranean, widely present in the Maghreb, and having strong similarities with Indian specialities.

The same deconstruction of a national stereotype could be operated for couscous, found in the Sicilian gastronomic tradition thanks to Arab influence and included in the first national canon of Italian cuisine, Pellegrino Artusi's $\mathrm{La}$ scienza in cucina e l'arte di mangiar bene (Science in the Kitchen and the Art of Eating Well) (1891).

Unsurprisingly, the Front National (Shields 2014) focused on the issue of halal meat, organizing an extremely vocal campaign around the fake news that all meat in France was halal. The Identitaires, an electorally weak and yet influential French political movement, was ahead of them: in 2014 the use of food in public events and political discourse became "a weekly occurrence" (Binet 2016, 240).

Xenophobia and mixophobia are likely to rub shoulders with localism. Cuisine and agriculture can provide good material for opposing both immigration and European policies, which French peasants perceive as hostile: an argument the Lega in Italy has recently picked up once more. The mixophobic discourse (Taguieff 2015) built on reactions against Americanization: criticism of the Islaburger combined opposition to Islamization as well as to Americanization. Raoul Bové and the Confédération Paysanne gave early voice to regional food, thus linking deep criticism of globalization with "authentic" French culture. They drew on the idea of the symbiotic relationship between people and landscape (Aron 1975). Their localism is certainly not "reflexive" (Goodman, Dupuis and Goodman 2012) or sophisticated. In Nice the Identitaires organized a combat gastonomique (gastronomic combat), while in Lyon they proposed a marche des cochons (a pigs' march), banned by the local authorities. They also organized pork-based soupes identitaires, broadly attended aperitifs called Apéro saucisson et pinard where sausages and French wine were served. One expression is recurrent in their rhetoric: souche (meaning "strain" in the ethnic sense), dear to the right wing of Action Française in the early 20th century. It may be worth adding that Action Française extended to the food issue (Saillard 2010).

In Italy such issues are reflected in two episodes where there is a clear reference to local and national gastronomic heritage as a closed system. The first is the closing down (or pressure to do so) of places serving ethnic dishes. The excuse given was a desire to protect local specialities against the growing popularity of ethnic cuisines. The second issue was the question of serving pork in school canteens where Muslim pupils may be present. The guidelines from Italian Minister of Education Maria Stella Gelmini in 2011 explicitly focused on the cultural and identity aspects of food in national terms. No reference was made to food as an intercultural factor helping to create a joint and more critical awareness, as the Caritas Report on Migrants pointed out. ${ }^{4}$ Admittedly, there are on record some attempts at innovation over extracurricular school 
activities involving learning about other cultures' food: cooking dishes together including diverse traditions, or learning about their entangled history. This was again mentioned by the Caritas report drawn up prior to Expo 2015 where the theme was “Feeding the Planet. Energy for Life!" But it is certainly not enough.

In some European countries, populist movements use food in order to "other" and reject "others". Paradoxically enough, in the United Kingdom curry (Collingham 2006) and chicken tikka masala (invented in England) came close to being national dishes. By 1997 a Gallup poll announced that curry was the nation's favourite food, and in 2001 British Foreign Minister Robin Cook declared that chicken tikka masala was Britain's national dish (Laudan 2013). Food critics, however, were more sceptical: they immediately called this dish a British invention: not a sign of multiculturalism, but a demonstration of Britons' ability to transform foreign foods into their own, as Jonathan Meades wrote in the Times (21 April 2001).

\section{9 th-century food nationalisms}

Speaking of gastrodiplomacy or gastronationalism for the 19th century would certainly be an anachronism. However, it was then that food entered powerfully into both the discourse and the practice of the nation.

Until the French Revolution, food symbolized first of all power and social distinction: for the wealthy it was largely "eating to impress" (Lloyd 2015). It was in the long 19th century that food became mostly a marker of national identity, while obviously continuing to mirror relations between individuals, social groups and the state (Spang 2000). Between the 18th and 19th centuries the meaning of "you are what you eat" started to change: dishes and cuisines helped to draw or to confirm old and new, existing or imagined geopolitical and mental boundaries. This process reached back to the already existing association of "national characters" with certain foods (as also with habits and look). Between the French Revolution and the Napoleonic Wars, the opposition between Englishness and Frenchness was increasingly represented through food: the beef-eating John Bull (invented 100 years before) became extremely popular as the hero of British liberty. The supposedly hearty diet of the British was represented as the opposite pole to the elaborate, effeminate diet of the French, to the point that beef and liberty became synonymous. At the same time, in the eyes of French travellers English people became rosbifs (Rogers 2004). Much later, in the interwar years and, more precisely, in 1934, Sir Henry Dixon Kimber added the concept of race when he wrote on behalf of the Hotels and Restaurants Association of Great Britain: "The French people are, by nature, as well as by training, for the most part instinctively cooks, in the true sense of the word. The British, as a race, are not, though there are many individual exceptions. But don't forget - different nationalities have different tastes, and employ different methods" (quoted in Mennell 1985, 279). 
In the early 19th century food started to identify the "we" of the invented national community against the "others". This represented a sharp turn from its previous use to signify divisions within society. It was then that the idea of the "middling cuisines" started to gain ground. According to Laudan, the "yawning gap between the food of the rich and the powerful and the food of everyone else within the state was diminishing. It was replaced by a different gap, a gap between the states where the shift to middling cuisines had occurred and the states that retained a sharp distinction between high and humble cuisines" (Laudan 2013, chapter 8). By the end of the 19th century, however, national cuisines were established in North America, Europe, Latin America and Japan, and were discussed in India and in various parts of the Ottoman Empire.

National thinking prompted the construction of national cuisines. This phenomenon should be read in the context of policies which promoted patrimonialization, as it was labelled in France, where the concept of heritage was born in the crucial years of the French Revolution. The new system of "museum, nation and heritage" (Poulot 1997) implied a deep change of perspective, which also directly affected the perception of cuisine. In his book Paris à table (1846) Eugène Briefault' declared that "la cuisine d'un peuple est le témoin exacte de sa civilisation" (a people's cuisine bears exact witness to its civilization) (quoted in Ory 1992, 823) and confirmed that the nation and its cuisine were one. In the Grande Nation and especially in Paris, restaurants were invented, cookbooks were published, the excellence of cuisine was emphasized and cooks policed the taste (Davis 2013). They became priests in a "properly national celebration" and looked for the roots of the nation, as did archaeologists and historians (Rowley 2006, 223).

Cuisine became an object of catalogues aiming at preservation, following the blueprint of the catalogues and musealizing of art heritage. In France shortly after the Revolution - that is, when the first museum of the monuments of the nation was created - the first inventory of the country's food was started as well.

I suggest we read the construction of a gastronomic identity as a policy similar to the creation of museums and centres for history studies. Research on this issue is still scant. However, there are interesting traces which ought to be followed up regarding more than one country. In 1859, shortly before Italian unification, scholars in Emilia creating one of the first regional institutions for the publication of historical sources urged the need to publish not only collections of local monuments and documents, but, equally important, to prepare inventories of bread shapes and special foods of the various provinces (Porciani 2018). In Spain in the 1870s, shortly after the foundation of the National Archaeological Museum dedicated to the protection, classification and exhibition of archaeological but also ethnographical items (Esteban deVega 2010, 126), a discussion about the gastronomic identity of the country was started by the father of national folklore, Antonio Machado y Alvarez. It was carried on under the auspices of the Centro de Estudios Historicos, founded in 1910, where historians and other scholars worked at a catalogue of historic 
Spanish traditions. The idea behind this research was that classic Spanish cuisine, enriched by many regional traditions, had been "slandered, forgotten and supplanted by the foreign fashion of French cuisine" (Ingram 2012, 9) and had to be rescued: thus Spain experienced its own version of gastronationalism (Riera i Melis 2004, 775).

While no national museum of food was created, the great international and national exhibitions which began in London in 1851 acted as a kind of Ersatz placing national foods on display (Scholliers and Teughels 2015). Such pavilions presenting food fall somewhat short of a museum but may at least be seen as temporary shows of food products, not only for commercial reasons, but also in order to present the variety of the various countries' edible heritage (Tellström, Gustafson and Lindgren 2008).

While shortly after the Revolution France was starting to recollect its food heritage, on the other side of the Atlantic Ocean the new republic of the United States of America in turn began shaping its national identity through culinary discourse and the unifying and civilizing practices of home cooking. After the American Civil War, the 1876 centennial encouraged further debates on national cuisine (Laudan 2013). American authors tried from very early on to define their national cuisine in opposition to Britain's. Corn "became a political instrument for self-definition and resistance, and laid the foundation for a republican cuisine" (Vester 2015). In neighbouring Canada, a cookbook written by the ladies of Toronto in 1878 complained that Canadians had no national dish to distinguish themselves from the British.

In Europe, after the defeat of the double monarchy in 1866, Hungarians nationalized goulasch (Metro-Roland 2013), a southern speciality until then ignored and considered vulgar. There was no question of sharing their culinary marker with the German victors (Rowley 2006, 324). Shortly after independence (1878), Romania also published its first book of recipes in the national language. Foreign names defining culinary specialities were avoided, especially on important events. In 1870s Spain criticisms were voiced of state banquets whose menus were written in bad French and not in Spanish. The same happened in Germany, where the Kaiser decreed that as far as possible imperial menus should be written in German (Heinzelmann 2014, 209). In this respect, Italy represents an exception, since the court cuisine remained French oriented while it was middle-class nationalism that pressed for a national cuisine (Montanari and Capatti 2003). In almost every country popular plates were named after kings, princes and princesses - the beloved icons of the nation. In Italy we find pizza Margherita (D'Achille 2017) and in England we see Prince Albert Pudding, while in Majorca the recipe of the sobressada was attributed to King Martin I of Aragon (Rowley 2006, 326). In Russia, where Tsar Nicholas I aimed at state-oriented patriotism focusing on "Russianness" and did not welcome "foreign" behaviour or cultures (Smith 2009), the topic of cuisine fell into the field of tension between Slavophiles and Westernizers. Faddej Bulgarin, in his popular weekly column in the Ekonom, praised Russian dishes as "simple, 
healthy, without any spices, without artifice, moral" as opposed to foreign food and spices (Smith 2009).

The deep divide between homely middle-class Russian food and foreign gastronomic foods was reflected in cookbooks. Restaurants followed. In Latvia at the beginning of the 19th century the top restaurants only served international cuisine, but after independence they started to serve only national cuisine.

Italy was probably an exception here: this "latecomer" to nation-building never developed a clear "national" culinary character. In fact, the acceptance of a plurality of traditions, already featured even in early modern cookbooks (Montanari 2013), was stressed even more in the years of annexation to Piedmont, when fear of standardization and Piedmontization was widespread. Parliamentary novels of post-unification Italy featured members of Parliament discussing the need to unify the national cuisine but also stressed the difficulty of doing so (quoted in La Cecla 2016, 51-2), while Pellegrino Artusi did not try to impose one gastronomic style but carefully noted and accepted diversity, as explained in the conclusion of this book.

\section{Women and cookbooks: gender and culinary nationalism}

Cuisine became one of the pillars of the new heritage community. At the centre of this community were women. Not by chance Marie-Antoine Carême began his L'Art de la cuisine française au dix-neuvième siècle (1833) with a discussion of pot-au-feu (boiled beef), the dish that holds the key to the French worker's diet and also lays the foundation for French cuisine as a whole, and began not with a recipe but with an analysis that details exactly what happens when the housewife sets her pot on the fire (Parkhurst Ferguson 2004,377). The nation may have been masculinized, given the centrality of the discourse on male bourgeois citizens and soldiers, but it was also feminized and familialized (Porciani 2002).

In the United States the close link between family and nation - reinforced thanks to the founding myth of American motherhood - was reaffirmed in the kitchen (Vester 2015). From independence on, the civilizing and domesticating role of middle-class white women in the United States was transmitted by textbooks of domestic economy written for women by women. Catherine Beecher's The American Woman's Home criticized British cuisine and, while not despising the French, did not fail to mention the "good patriots" or the good culinary habits of the grandmothers (Beecher 1869, 171, 176). In 1846 Sarah Josepha Hale launched a campaign to celebrate Thanksgiving as the national holiday commemorating unification, expansion and inclusion around the dinner table and the turkey. Godey's Lady's Book (1865) - the American woman's bible of domestic science that would see out the century - urged its readers to support this influential ritual rooted in domestic life (Porciani 2008). Many 
of these cookbooks were written by Presbyterian churchwomen, prefaced by ministers and sold for charity (Laudan 2013).

In Europe women wrote cookbooks almost everywhere (Montanari 2013): Magdalena Dobrumila Rettigovà provided Czech cuisine with its bible, and Katharina Prato was the author of a monumental cookbook running to more than 700 pages. They were not alone, as Catherine Horel points out in this volume (Chapter 8). In Denmark, recipe books written by women and focusing on the perception of nation-building in the throes of heavy territorial losses promoted the consumption of Danish products and the education of good citizens. Thus they voiced women's need to be "useful for our fatherland". It is therefore not surprising that cookbook authors were explicit about not using foreign names (Gold 2007, 98-102): a choice made elsewhere too, and similar to the deep criticism of "foreign" nannies for the young generation in many countries.

In Russia cookbooks were also often written by women: the most popular cookbook author in the country was probably K.A. Andreeva, who labelled herself as an "experienced Russian housewife" (Smith 2012, 456).

"[A] cookbook that consisted of nothing but rules for various dishes would be an unpopular cookbook indeed. Even the root of recipe - the Latin recipere implies an exchange, a giver and a receiver. Like a story, a recipe needs a recommendation, a context, a point, a reason to be" (Roy 2002, 478). Some of them provide narratives and even a feminine genealogy (the cooking of the mother or the grandmother). Others constitute a sort of autobiography of the nation, and are even chosen as national icons. Three years after publication of the first historical study ever written in Lithuanian (Selenis 2010), in 1845, it was a (noble) woman, Anna Ciundziwicka, who oriented greater Lithuanian culinary history with a book titled Lithuanian Housewife, which was followed six years later by Wincentyna Zawadzka's Lithuanian Housewife (Belyi 2013). However, the first cookbook in the Lithuanian language (again titled Lithuanian Housewife and likewise authored by a woman) was not published until 1893. The importance as well as persistence of this national turn should not be exaggerated: in relation to food the elite of the new interwar Lithuanian Republic concentrated on other issues - less important for the focus of this book - but rational, scientifically correct and healthy food preparation indebted to the Western model was not the least important of them.

At the turn of the century, when a further shift took place - from the Kulturnation to the ethnic nation - women were once more at the centre of the picture. In 1894 Alfred Suzanne, introducing his La cuisine anglaise et la pâtisserie, wrote: "In France women need not learn cookery. It is inborn" (quoted in Saillard 2014). Action Française had already devoted attention to French cooking, but it was in the interwar years that such statements took a clear step further. In his novel on La vie et la passion de Dodin-Bouffant, gourmet (1924), the historian and writer Marcel Rouff declared: "la gastronomie est innée dans la race" (gastronomy is innate to the race). The model at this point 
is clearly the peasant woman "de souche" who never learned cooking at school or in books, because "elle la savait de naissance et par atavisme" (she knew it from birth, atavistically) (quoted in Rowley 2006, 338). This statement recalls the widespread discourse on women's ancestral memory in the same period (Porciani 2008). In the 1930s, while praising the excellence of French cuisine, the middle-class women's magazine Elle cautiously presented a few exotic dishes, introducing them explicitly as "alien” (Régnier 2005, 3).

In the interwar republic it was the Lithuanian Women's Catholic Association that published a magazine and promoted a book of recipes which described the main dishes of the culinary heritage of the four principal ethnic groups, and published the oldest recipe for Lithuanian zeppelins (cepelinai): potatoes stuffed with chopped meat (Belyi 2013), while in the neighbouring Belarus republic the most vivid contribution to the idea of Belorussian culinary heritage was The New Land by Yakub Kolas, an epic poem in Belorussian which described peasant meals at length. The culinary roots were to be found in peasant life.

In Serbia, Slovenia and Croatia women also wrote national cookbooks, carefully differentiating them from those drawing on foreign sources. None of them, however, mirrored a Yugoslavian identity. It was only in socialist Yugoslavia that the former head chef for Tito, Olga Novak-Markovič, tried to blend the nation's dishes into a cuisine characteristic of Yugoslavia as a whole (Bracewell 2012; Saillard 2014).

In Spain, after the First World War, novelist Emilia Pardo Bazan "pleaded for the nationalization of domestic practices" (Storm 2016, 184) and "urged her listeners to thoroughly hispanicize their homes, beginning with the cuisine" (Gutiérrez 2017) and argued that they should cook Spanish dishes, in line with which she published La cocina antigua española. Gastronationalism became intense under Franco: only from the late 1960s on did regional or international gastronomic traditions start to re-emerge (Anderson 2013a, 2013b; Ingram 2012; Riera i Melis 2004, 775, 780).

Clearly, gender, nation and food form a complex strand. National dishes especially if related to fire and open-air cooking - often seem connected with masculinity: this is so with the barbecue or the Mexican barbacoa. This issue is extremely important in connection with dishes perceived as national. Barbecuing is also a beloved male activity of Israeli Jews celebrating the nation's independence day (Avieli 2013) while paella too was originally a dish prepared by men on an open fire. It only later became part of women's cuisine when it was brought inside and cooked in the kitchen (Duhart and Medina 2007; Guardiola y Ortiz 1972).

Useful prompts for thinking about food-nation-gender tie-ups also emerge from new case studies focusing on the perception and custody of traditional identity-linked factors in relation to conflict over statehood. Among Israel's Palestinians only the menfolk cook in public establishments, in which Palestinian women do not figure at all. These Palestinian male cooks prefer to serve dishes not directly connected to their own tradition. For traditional 
cooking, the perceived heritage of the Palestinian people is the women's province within the family nucleus, as though it were women, retaining the secret recipes and food customs of tradition, who cultivate the nation inside the private, though political, domain of the home. They refuse to let it be commodified in restaurants of outsiders, where it would so easily get shared or watered down: in a word, dispersed or perverted. As Gvion writes, it is partly by preserving a distinction between home cooking and food consumed in public places that Palestinians express their resistance to the status they have been given in Israeli society and "become active social agents engaged in controlling the appropriation and modification of Palestinian food by Jewish culinary agents" (Gvion 2011, 411). Studies on masculinity start focusing on the issue of food (Neuman 2017; Neuman and Fjellström 2014). As cooking shows are reaching the status of icons, scholars have also started to reflect on the image of masculinity that they convey (Leer 2016).

\section{Coda: about this book}

The story of food nowadays associated with one nation state is often a story of remote transfers owing to usually overlooked long-distance travel and migrations: when we eat tempura in a European Japanese restaurant looking for something new, we do not think that Japan adopted tempura from Portuguese visitors and returned it to Europe with migrants of its own (Fernández-Armesto and Sacks 2012).

Exchanges have always marked the history of ingredients and cuisines. Hence, it is important to avoid any temptation of methodological nationalism which might encourage one to rethink cooking traditions within the nation states' borders. Contacts and transfers took place right from ancient times: the ones attested within the Roman Empire were not the first.

In this book Massimo Montanari focuses on the integration of Europe's culinary models in the Middle Ages and on their syncretism. The opposition between food regimes of different religious groups was apparently marked by clear-cut boundaries: Christians had a well-defined liturgical year interspersed with periods of fasting, Muslims had Ramadan and Jews ate special foods for specific festivities. The interdicts on pork for Muslims and on pork and other kinds of meat for Jews strongly differentiated their cooking. Yet recent studies on the eating habits and identity of Jewish communities point out not only the dynamic, porous and constantly evolving character of their recipes and the process of differentiation of some Jewish dishes from "local" cuisines (Roden 1974), but also the many changes and hybridization of original recipes of distinct Jewish groups, which could not always follow their tradition because they had to use what was locally available (Toaff 2004).

The crusades fostered new eating experiences and culinary habits. Much more decisive, however, was the Columbian exchange (Crosby 1972), which opened the way to many culinary discoveries (Earle 2012; Pérez Samper 2012) 
and reciprocal transfers from the old world to the new and beyond, as triangulation through Africa makes clear. The turkey's French name, dinde - that is, "d'Inde" (from the West Indies) - still bears evidence of its exotic origin. At first it was only eaten in well-defined geographic areas such as Genoa and eastern Iberia, and especially in specific social milieus (Genoese merchants and Spanish nobility), but it was soon incorporated in many European diets. However, it took time before some of the plants and animals introduced on either side became widely accepted and were incorporated in previous eating regimes. The history of the potato and its slow reception is exemplary in this respect. It was not until the mid-17th century, after the destruction, reconstruction and reintegration of food in the new world and in Africa, Europe and Asia, that new animals and edible plants were adopted in hybrid cuisines (Mintz and Friedmann 2004, 421). The fact that new cereals and vegetables reached Europe did not make them immediately accepted or popular there when they first arrived. Corn and tomatoes made their way through Catalonia and western Liguria before becoming core components of many recipes in southern France and Italy.

The long 19th century was much more an age of empires than of nations and nation states (Osterhammel 2014, 392). It is impossible to imagine Britain without the empire. Throughout the long 19th century edibles constituted the majority of the value and weight of Britain's imperial trade (Bickham 2008, 72). These products coming from the empire penetrated the daily life of men and women. Their advertisements were more pervasive than any other print media. Not only images of the British colonies and imperial trade abounded in British advertisements for empire-related foods: "Britannia, the symbolic embodiment of Britain, appears regularly with her spear and shield before bowing imperial subjects offering imperial foods and goods as a form of tribute" (Bickham 2008, 81-92). British cooking was marked by an increasing presence of "Currey the India way", which appeared for the first time in Hannah Glasse's Art of Cookery Made Plain and Easy (1747). With the "increasing racialization of the Raj after 1857, the body of British official in India became an even more powerful sign of 'Britishness' and diet and dress become, accordingly, cultural sites on which a sense of bodily difference between the British and their Indian subjects was maintained" (Sengupta 2010, 84). The flavours of Indian cuisine and the spices brought back by the East India Company's nabobs (Collingham 2006; Colquhoun 2011) were soon transformed into new recipes and foods: curry was rapidly interpreted as a ready mixture of spices soon to be called "Curry powder". This mixture was sold as early as 1784 in London and soon curry became a national dish. In spite of all these entanglements, however, British cooking apparently remained extremely conservative until the 1960s: only then did restaurants run by immigrants from Italy, China or the Indian subcontinent start to become popular (Mason 2004).

Innovative and even cosmopolitan restaurants (Assael 2013), together with ethnic and colonial shops or the large stores which started to appear at the 
turn of the 20th century especially in the metropolis and capital cities, started to offer a variety of exotic products, in implicit opposition with the market halls, so deeply connected with local food and recently turned into heritage and memory places (Fava, Garcia, Plana and Garrido 2016). In food exchanges empires were crucial: they introduced innovations and forced a metropolitan taste on peripheral areas, as well as providing institutional and geopolitical opportunities for mobility of merchants, civil servants and the armed forces, who took with them cookbooks, cooks and maids, thus hybridizing culinary traditions, as Samanc1 (Chapter 9) and Horel (Chapter 8) point out in this book.

No less important, however, were various other kinds of people on the move. Travellers and later tourists imported new tastes and opened the path not only to "typical" or "ethnic" restaurants in Europe, but to a reshaping of exotic cuisines which adapted to their consumers' taste and expectations. Much later, students, especially after 1968 and increasingly with the Erasmus and Overseas programmes, have also contributed to such hybridization of gastronomic cultures and eating habits.

Diasporas (Mintz 2008) and exiles (Fernández-Armesto and Sacks 2012) in turn introduced and popularized new foods, and still do. So too did various waves of emigration and immigration (Beer 2014). In recent times, these experiences also started to be mirrored in some temporary or permanent exhibitions, complementing the static and often national approach of many museums dealing with food. In fact, museums can turn into visual and sensory experience the notion of what food was and is. They often suggest nostalgia for a mythical past, prior to industrialization, globalization, and what is perceived altogether as decline. Sometimes, however, they try to play their role in the field of public history and take account of the historian's work. In Plymouth Plantation historians have documented 17th-century English and Native American foodways, have given attention to those dynamics that changed both groups as a result of their interaction, and have "deconstructed and dismissed the mythologies central to a nationalist ideology, and have reinterpreted an early meeting, commonly and mistakenly referred to as 'the First Thanksgiving', between Wampanoags and Pilgrims. The resultant recasting successfully offered through food history a new context for the interpretation of Native American history, settler history, and environmental history" (Green 2012, 86). This attention to the new history of food is to some extent mirrored in the Brussels House of European History, which provides a concise presentation of food transfers within European countries and across the Mediterranean. Through displays that focus on culinary cultures, museums - as Susannah Eckersley shows in this book (Chapter 6) - can also answer to a desire for public recognition of difficult past times and deal with themes of multiculturalism, migration and intercultural contact, providing a kind of "safe space" to explore differences otherwise difficult to deal with.

Unsurprisingly, the topic of migrations has largely been investigated for Italian Americans in connection with the image of the country, in studies 
which are relevant to the approach of this book (Caldognetto 2014; Cinotto 2017; Cinotto, Canepari and Regnard-Drouot 2016; Corti 1998; Diner 2001; Gabaccia 1998; Scarpellini 2016). Italians in the United States of the late 19th and early 20th centuries emphasized the link between their products and some of their nation's icons, projecting the pride of a Kulturnation onto commodities. Garibaldi's immense popularity in 19th-century England explains the name of popular cookies, still produced today. One olive oil brand was soon named after Dante, while advertising of other produce displayed images of famous Italian monuments: a process that also occurred in Italy, as Paolo Capuzzo points out in this book (Chapter 4).

In closing this introduction, I would like to refer to recent works which highlight the use of national heritage in order to promote not only food, but restaurants. Maren Möhring studied the evocative power of monuments in the prints and pictures adorning the walls of Italian restaurants in Germany from the 1950s onwards in an attempt to reconstruct an Italian atmosphere (Möhring 2012, 258, 267-8). Further investigations of the commercial strategies of governments, producers and tourist agencies would certainly help us to understand the intertwining and overlapping of artistic and food heritages that occurs in branding. It was not possible to further develop this issue here, neither was it possible to explore the role played - albeit at a very different level - by exiles: in this book this topic is only touched on by Tolomelli (Chapter 5).

From different points of view this introduction and the 11 chapters of this book investigate the interweaving of discourses on food and to a varying extent cooking practices, heritagization and nationalism. These narratives grew out of largely invented foundation myths and traditions of individualism and nationality. The authors of this book do not share the framework of unreflective nationalism. Thus we have chosen to avoid chapters focusing on individual countries: Paolo Capuzzo's contribution (Chapter 4) - mostly but not exclusively on Italy - is thus an exception: its importance lies in exploring the dynamics and political nature of the regional or local dimension in a 200-year span from nationalism, through Fascism, down to the mass television culture and the miracolo economico (the Italian economic miracle or boom). Instead of focusing on individual countries, we have chosen to cast light on transnational spaces, from medieval Europe to the empires. We have drawn attention to the global scene which quality labels and intangible heritage impact (Parasecoli, Chapter 3, and Di Fiore, Chapter 2), conscious that even when Europe is at the core of our research, it is a Europe with porous and open borders, increasingly connected.

In many ways we have insisted on one point: that place-bound formal heritagization may present problems. Di Fiore suggests that such processes often minimize history and change (in the conclusion to this book Massimo Montanari and I have called this time) in favour of place-bound invented traditions (in the conclusion we have called this place). History and geography are the historian's eyes, from Herodotus onwards. It is important to map 
change - persistence but most of all innovations in a geography free from constraints: a geography which does not passively mirror the methodological nationalism of nation-state borders, but opens up to dynamism.

Many themes recur in this book's various chapters. Gender is one of them, and intersects with this introduction as well as Williot's (Chapter 10) and Di Fiore's (Chapter 2) contributions and the chapters on empires (Chapters 3 and 4), on 1968 (Chapter 5) and on museums (Chapter 6).

Class is certainly another issue that crosses most of the chapters of this book, including this introduction. National imagination created around food, and eventually a national cuisine, tended to overshadow the fact that often the "national diet" was in fact not the same for everybody: poor people had access to a limited supply of food and were certainly not the intended public of recipe books. Only in post-war situations and countries with wide-scale literacy was food shortage addressed, albeit indirectly, and the authors of cookbooks did not refrain from pointing out that certain ingredients needed in cooking typical dishes were expensive and beyond some people's means.

Differences of class and milieu intersecting with local peculiarities have always been relevant. Massimo Montanari points out that the lower classes were for a long time limited in their consumption to what was produced in the area. It was the signori (the nobility and the gentry) who were not so restricted: there was a clear gap between what the courts and the aristocracy ate and what the workers could afford: often one single food, and not even enough of it. Wine conquered the beer countries fairly early, but was only drunk by the elites; Catherine Horel (Chapter 8) points out that there was - as expected - a great difference between what the lower classes and the upper classes drank.

Catherine Horel highlights also the mobility of civil servants and cooks, while peasants were sedentary. Having access only to local food, they were more conservative in taste and eating habits. The urban middle classes were more experimental, especially in an empire. In a different context it was middle-class stateless refugees from the former Russian Empire who created a distinctive vibrant consumer economy in international cities and were active in opening restaurants and importing new food heritage to such places as cosmopolitan Shanghai with its community of merchants and traders. It was the middle classes that ate in Shanghai restaurants in the 1920s and 1930s, as Katya Knyazeva remarks (Chapter 11). Social stratification is also considered in Capuzzo's contribution (Chapter 4), which focuses especially on the role of the middle classes. Fabio Parasecoli (Chapter 3) suggests we should connect social milieus with taste. Features that in the past were a cause for shame, such as the simplicity of dishes, the rusticity of ingredients and the connection with rural and workingclass social environments, have turned into major advantages in the process of re-evaluation that characterizes contemporary food culture.

Essential, ethnic food rooted in a single locality hardly exists. And yet nostalgia is a central topic to many of the chapters of this book. As we have briefly recalled, however, exchanges were a persistent and crucial factor, as has been 
the role of diasporas, colonization and decolonization, commercial and colonial trade (Knyazeva, Chapter 11), older and more recent mass migrations, but also movements like those of 1968, where a new generation became increasingly open and experimental, and its criticism of traditional foodways revealed scope for experiments perceived and labelled as new on both sides of the Atlantic (Tolomelli, Chapter 5). Each of them contributed to the food's geteilte Geschichte.

Many chapters of this book emphasize not only the well-known opposition between town and country, but more specifically the role of capital cities such as Paris, the capital not only of France, but also of the long-lasting French hegemony over haute cuisine;Vienna and Istanbul were true melting pots, but so too were important harbours in Europe, in the colonies and in the imperial ambit. Fiume is a good case in point.

Tensions between local and national on one hand, and global on the other, are present in various chapters: they could be read as a fil rouge running throughout this volume, from this introduction to Di Fiore's contribution (Chapter 2) which points out that in UNESCO candidature local becomes national on the global scene - to the chapter authored by Fabio Parasecoli (Chapter 3).

The chapters of this book implicitly allude to some further common themes. As a parting shot to this introduction, I invite readers to spot these, and to read this book both as a summing up of three fertile decades of study and as a springboard for other more specific research.

\section{Notes}

1 UNESCO nomination file number 01063 for inscription on the representative list of the Intangible Cultural Heritage of Humanity.

2 www.gamberorosso.it/it/news/1026133-1-istituto-nomisma-spiega-all-italia-cos-ela-gastro-diplomazia-il-soft-power-di-cibo-e-cucina accessed December 2018.

3 www.20minutes.fr/societe/2201303-20180113-unesco-emmanuel-macronsouhaite-baguette-inscrite-patrimoine-mondial-humanite; http://gastronomiquementvotre.blogspot.com/2008/09/le-patrimoine-alimentaire-definition.html accessed December 2018.

4 Caritas e migrantes. XXIV rapporto immigrazione e sviluppo: http://inmigration.caritas. it/sites/default/files/2016-09/XXIV\%20Rapporto\%20Immigrazione\%202014.pdf accessed December 2018.

\section{References}

Adell, N., Bendix, R., Bortolotto, C. and Tauschek, M. (2016) "Introduction", in N. Adell, R. Bendix, C. Bortolotto and M. Tauschek (eds), Between Imagined Communities and Communities of Practice Participation, Territory and the Making of Heritage, Göttingen: Göttingen University Press, 7-24.

Alonso, A. and Krajsic, V. (2013) "Food heritage down under: olive growers as Mediterranean 'food ambassadors", Journal of Heritage Tourism 8(2-3): 158-71. 
Anderson, L. (2013a) Cooking Up the Nation. Spanish Culinary Texts and Culinary Nationalization in the Late Nineteenth and Early Twentieth Century, Woodbridge: Tamesis.

Anderson, L. (2013b) “The unity and diversity of La olla podrida: an autochthonous model of Spanish culinary nationalism", Journal of Spanish Cultural Studies 14(4), 400-14.

Appadurai,A. (1996) "Global ethnoscapes: notes and queries for a transnational anthropology”, in A. Appadurai, Modernity at Large: Cultural Dimensions of Globalization, Minneapolis: University of Minnesota Press, 48-65.

Ariel, A. (2012) “The hummus wars”, Gastronomica 12(1): 34.

Aron, J.P. (1975) The Art of Eating in France: Manners and Menus in the Nineteenth Century, London: Peter Owen.

Assael B. (2013) "Gastro-cosmopolitanism and the restaurant in late Victorian and Edwardian London”, Historical Journal 56(3): 681-706.

Avieli, N. (2013) “Grilled nationalism”, Food, Culture \& Society 16(2): 301-20.

Aykan, A. (2016) "The politics of intangible heritage and food fights in Western Asia”, International Journal of Heritage Studies 22(10): 799-810.

Barham, E. (2003) "Translating terroir: the global challenge of French AOC labeling”, Journal of Rural Studies 19: 127-38.

Barthes, R. (1961) "Pour une psycho-sociologie de l'alimentation contemporaine", Annales 16(5): 977-86.

Baumann, Z. (2000) Liquid Modernity, Cambridge: Polity Press.

Beecher, C. (1869) A Treatise on Domestic Economy, for the Use of Young Ladies at Home, and at School, Boston, MA: T.H.Webb.

Beer, M. (2014) Über den tellerrand geschaut. Migration und Ernährung in historischer Perspektive (18. bis 20. Jahrhundert), Essen: Klartext.

Bendix, R., Eggert, A. and Peselmann, A. (eds) (2012) Heritage Regimes and the State, Göttingen: Universitätsverlag Göttingen.

Bessière, J. (2001) Valorisation du patrimoine gastronomique et développement territorial: le Haut Plateau de l'Aubrac, Le Pays de Roquefort et le Périgord Noir, Paris: L'Harmattan.

Bessière, J. (2010) "Patrimoine alimentaire et innovations. Essai d'analyse typologique sur trois territoires de la Région Midi-Pyrénées", ISDA. https://hal.archives-ouvertes.fr/ hal-00521740

Bessière, J. and Tibère, L. (2010) L'innovation dans les processus de valorisation des patrimoines alimentaires en espace rural. Étude pour la mise en place d'outils de gestion et d'accompagnement, Versailles: Editions Quae.

Biasin, G. (1991) I sapori della modernità. Cibo e romanzo, Bologna: Il Mulino.

Bickham, T. (2008) "Eating the empire: intersections of food, cookery and imperialism in eighteenth century Britain", Past and Present 198: 71-109.

Billig, M. (1995) Banal Nationalism, London: SAGE.

Binet, L. (2016) “'Touche pas à mon pain au chocolat!' The theme of food in current French political discourses", Modern \& Contemporary France 24(3): 239-52.

Blom, I., Hagemann, K. and Hall, C. (2000) Gendered Nations: Nationalisms and Gender Order in the Long Nineteenth Century, Oxford-New York: Berg.

Boym, S. (2001) The Future of Nostalgia, New York: Basic Books. 
Bracewell, W. (2012) "Eating up Yugoslavia: cookbooks and consumption in socialist Yugoslavia", in P. Bren and M. Neuburger (eds), Communism Unwrapped. Consumption in Cold War Eastern Europe, New York: Oxford University Press, 169-96.

Caldognetto, M.L. (2014) "Storia e memoria di sapori e saperi: la forza del territorio nella cultura del cibo italiano oltre frontiera", in M.L. Caldognetto and L. Campanale (eds), Tra innovazione e tradizione, un itinerario possibile, Luxembourg: Convivium, 179-229.

Chapple-Sokol, S. (2013) "Culinary diplomacy: breaking bread to win hearts and minds", The Hague Journal of Diplomacy 8: 161-83.

Chen,Y.-J. (2011) "Ethnic politics in the framing of national cuisine", Food, Culture and Society 14(3): 315-33.

Chong, J. (2012) "Mine, yours or ours? The Indonesia-Malaysia disputes over shared cultural heritage", SOJOURN: Journal of Social Issues in Southeast Asia 27(1): 1-53.

Cinotto, S. (2017) "Immigrant tastemakers: Italian cookbook writers and the transnational formation of taste in the postindustrial United States, 1973-2000", in J. Sciorra and L. Ruberto (eds), New Italian Migrations to the United States, Vol. 2, Urbana: University of Illinois Press, 139-66.

Cinotto, S., Canepari, E. and Regnard-Drouot C. (2016) Food, Migration, and Mobility in Historical Perspective: Nineteenth to Twenty-First Century, special issue, Quaderni Storici 151.

Clough, E. (2015) "The politics of food labeling and certification", in R.J. Herring (ed.), The Oxford Handbook of Food, Politics, and Society, Oxford: Oxford University Press.

Cohen, E. and Avieli, N. (2004) "Food in tourism: attraction and impediment", Annals of Tourism Research 31(4): 755-78.

Collingham, L. (2006) Curry: A Tale of Cooks and Conquerors, New York: Oxford University Press.

Colquhoun, K. (2011) Taste: The Story of Britain through Its Cooking, London: Bloomsbury.

Corti, P. (1998) "Emigrazione e consuetudini alimentari. L'esperienza di una catena migratoria", in Storia d'Italia, Annali, vol. 13, Turin: Einaudi, 681-719.

Counihan, C. (1999) The Anthropology of Food and Body: Gender, Meaning and Power, New York: Routledge.

Counihan, C. and Kaplan S.L. (1998) Food and Gender: Identity and Power, Amsterdam: Harwood Academic Publishers.

Crosby, A. (1972) The Columbian Exchange: Biological and Cultural Consequences of 1492, Westport, CT: Greenwood Publishing Group.

Csergo, J. (2016) La gastronomie est-elle une merchandise culturelle comme une autre? La gastronomie française à l'UNESCO: histoire et enjeux, Laballery, Paris: Menu Fretin.

Cwierta, K.J. (2006) Modern Japanese Cuisine. Food, Power and National Identity, London: Reaktion Books.

D’Achille, P. (2017) Che pizza!, Bologna: Il Mulino.

Davis J.J. (2013) Defining Culinary Authority: The Transformation of Cooking in France, 1650-1832, Baton Rouge: Louisiana State University Press.

de Soucey, M. (2010) "Gastronationalism. Food traditions and authenticity politics in the European Union", American Sociological Review 75(3): 432-55.

Delfosse, C. (1997) "Noms de pays et produits du terroir: enjeux des dénominations géographiques”, Espace géographique 26(3): 222-30. 
Delfosse, C. (ed.) (2011) La mode du terroir et les produits alimentaires, Paris: Les Indes savantes.

Demossier, M. (2016) "The Europeanization of terroir: consuming place, tradition and authenticity", in R. Friedman and M. Thiel, (eds), European Identity and Culture: Narratives of Transnational Belonging, London-New York: Routledge, 119-36.

Di Fiore, L. (2018a) "Patrimoni di origine protetta. Le procedure di Food Labelling nelle istituzioni internazionali all'incrocio tra nazionale, globale e locale", Storicamente 14(2): doi: 10.12977/stor692.

Di Fiore,L. (2018b) “Bibliography “Food as Heritage”, Storicamente 14(3): doi: 10.12977/ stor696.

Di Giovine, M. and Brulotte, R. (2014) "Introduction: food and foodways as cultural heritage", in M. di Giovine and R. Brulotte (eds), Edible Identities: Food as Cultural Heritage (Heritage, Culture and Identity), New York: Routledge, 1-28.

Diner, H.R. (2001) Hungering for America: Italian, Irish, and Jewish Foodways in the Age of Migration, Cambridge, MA: Harvard University Press.

Douglas, M. (1966) Purity and Danger: An Analysis of Concepts of Pollution and Taboo, London: Routledge.

Duhart, F. and Medina, F. (2007) "La paella domestiquée (Espagne, France). Rèflexions sur l'entrée en cuisine d'n plat venu des champs", in G. Cazes-Valette (ed.), Faire la cuisine. Analyses pluridisciplinaires d'un nouvel espace de modernité, Paris: OCHA, 162-8.

Durand, G. (1992) "La vigne et le vin”, in P. Nora (ed.), Les lieux de mémoire, vol. 3.2, Paris: Gallimard, 784-821.

Duruz, J. (1999) "Food as nostalgia: eating the fifties and sixties", Australian Historical Studies 29(113): 231-50.

Earle, R. (2012) The Body of the Conquistador: Food, Race and Colonial Experience in Spanish America, Cambridge: Cambridge University Press.

Esteban de Vega, M. (2010) "Spain”, in I. Porciani and L. Raphael (eds), Atlas of European Historiography. The Making of a Profession 1800-2005, Basingstoke: Palgrave Macmillan.

Evans E. (1942) Irish Heritage. The Landscape, the People and Their Work, Dundalk: Dundalgan Press.

Everett, S. and Aitchison, C. (2008) "The role of food tourism in sustaining regional identity: a case study of Cornwall, south west England", Journal of Sustainable Tourism 16(2): 150-67.

Fava, N., Garcia, M., Plana, L. and Garrido, R. (2016) “Food public markets as cultural capital: Girona province", in C. Hein (ed.), International Planning History Society Proceedings, 17th IPHS Conference, History-Urbanism-Resilience, Tu Delft Open. doi: http://dx.doi. org/10.7480/iphs.2016.3.1253

Fernández-Armesto, F. and Sacks, B. (2012) “The global exchange of food and drugs", in F. Trentmann (ed.), The Oxford Handbook of the History of Consumption, OxfordNew York: Oxford University Press, 127-44.

Fischler, C. (1988) "Food, self and identity", Social Science Information 27: 275-93.

Flandrin, J.L. (1999) "Dietary choices and culinary technique, 1500-1800", in J.L. Flandrin and M. Montanari (eds), Food. A Culinary History, New York: Columbia University Press, 403-17.

Flandrin, J.L. (1992) Chronique de Platine: pour une gastronomie historique, Paris: Jacob. 
Flandrin, J.L. (2000) La blanquette de veau: histoire d'un plat bourgeois, Paris: Jean-Paul Rocher.

Fox, R. (2007) "Reinventing the gastronomic identity of Croatian tourist destinations", International Journal of Hospitality Management 26(3): 546-59.

Frattini, D. (2017) "Israele, la disfida dello 'zataar' l'erba dell'anima palestinese" Corriere della Sera 4 May 2017, p. 19.

Friedman, P. (ed.) (2007) Food, the History of Taste, London: Thames \& Hudson.

Gabaccia, D.R. (1998) We Are What We Eat: Ethnic Food and the Making of Americans. Cambridge, MA: Harvard University Press.

Gellner, E. (1983) Nations and Nationalism, Ithaca, NY: Cornell University Press.

Gold, C. (2007) Danish Cookbooks: Domesticity \& National Identity, 1616-1901, Seattle: University of Washington Press, Copenhagen Museum Tusculanum Press, University of Copenhagen.

Goodman, D., Dupuis, E.M. and Goodman M.K. (2012) Alternative Food Networks. Knowledge, Practice and Politics, London-New York: Routledge.

Gössling, S. and Hall, C. (2013) "Sustainable culinary systems: an introduction", in S. Gössling and C. Hall (eds), Sustainable Culinary Systems: Local Foods, Innovation, Tourism and Hospitality, London-New York: Routledge, 3-44.

Green, R. (2012) "Public histories of food", in J.M. Pilcher (ed.), The Oxford Handbook of Food History, Oxford: Oxford University Press, 81-96.

Guardiola y Ortiz, J. (1972), Gastronomía alicantina, Alicante: Agatángelo Solar Llorca.

Gutiérrez de Armas, J. (2017) "Gastronomía y construcción de la identidad nacional en Canarias, Un estudio de caso a partir de los recetarios del archivo Conde de Siete Fuentes (1880-1930)", Revista de Dialectologia y Tradiciones Populares LXXII(2): 533-54.

Gvion, L. (2011) “Cooking, food, and masculinity: Palestinian men in Israeli society”, Men and Masculinities 14(4): 408-29.

Han, K.K. (2011) “The 'kimchi war' in globalizing East Asia: consuming class, gender, health and national identity", in L. Kendall (ed.), Consuming Korean Tradition in Early and Late Modernity. Commodifications, Tourism and Performance, Honolulu: University of Hawaii Press, 149-66.

Hannerz, U. (2006) “Cosmopolitanism”, in J.Vincent and D. Nugent (eds), A Companion to the Anthropology of Politics, Oxford: Blackwell, 69-85.

Haraldsdóttir, L. and Gunnarsdóttir, G. (2014) “Pure, fresh and simple. 'Spicing up' the New Nordic Cuisine", in Joliffe L. (ed.) Spices and Tourism: Destinations, Attractions and Cuisines, London: Short Run Press, 169-81.

Harrington, R. and Ottenbacher, M. (2010) "Culinary tourism - a case study of the gastronomic capital", Journal of Culinary Science \& Technology 8(1): 14-32.

Hartog, F. (2015) Regimes of Historicity. Presentism and Experiences of Time, New York: Columbia University Press.

Heinzelmann U. (2014) Beyond Bratwurst: a history of food in Germany. London: Reaktion Books.

Hertz, E. (2017) "Bottom, genuine and spurious", in N. Adell, R. Bendix, C. Bortolotto and M. Tauschek (eds), Between Imagined Communities and Communities of Practice: Participation, Territory and the Making of Heritage, Göttingen: Göttingen University Press, 25-57.

Hobsbawm, E. (1983) "Introduction: inventing tradition", in E. Hobsbawm and T. Ranger (eds), The Invention of Tradition, Cambridge: Cambridge University Press, 1-14. 
Hobsbawm, E. (1990) Nations and Nationalism since 1780: Programme, Myth, Reality, Cambridge: Cambridge University Press.

Hobsbawm,E.and Ranger,T.(eds) (1983) The Invention of Tradition, Cambridge: Cambridge University Press.

Holak, S. (2014) "From Brighton Beach to blogs: exploring food-related nostalgia in the Russian diaspora”, Consumption Markets \& Culture 7(2): 185-207.

Holtzman J.D. (2006) "Food as memory", Annual Review of Anthropology 35: 361-78.

Ichijo, A. and Ranta, R. (2016) Food, National Identity and Nationalism: From Everyday to Global Politics, Basingstoke: Palgrave Macmillan.

Ingram, R. (2012) "Mapping and mocking: Spanish cuisine and Ramón Gómez de la Serna's 'El primer mapa gastronómico de España"”, Cincinnati Romance Review 33: 78-97.

Kaya, A. (2019) Populism and Heritage in Europe: Lost in Diversity and Unity, London: Routledge.

Kaya,A.and De Cesari,C.(eds) (2019), Populism and Memory in Europe,London: Routledge.

Kirshenblatt-Gimblett, B. (2004) "Foreword”, in L. Long (ed.), Culinary Tourism: Material Worlds, Lexington: University Press of Kentucky, xi-xiv.

Kuutma, K. (2012) "Between arbitration and engineering: concepts and contingencies in the shaping of heritage regimes", in R. Bendix, A. Eggert and A. Peselmann (eds), Heritage Regimes and the State, Göttingen: Universitätsverlag Göttingen, 21-38.

La Cecla, F. (1997) Il malinteso, Rome-Bari: Laterza.

La Cecla, F. (2016) Babel food. Contro il cibo kultura, Bologna: Il Mulino.

Laudan, R. (2013) Cuisine and Empire. Cooking in World History, Berkeley-Los AngelesWashington: University of California Press.

Leer, J. (2016) "What's cooking, man? Masculinity in European cooking shows after The Naked Chef”, Feminist Review 114: 72-90.

Lévi-Strauss, C. (1958) Anthropologie structurale, Paris: Plon.

Lloyd, P. (2015) Food and Identity in England, 1540-1640: Eating to Impress, LondonNew York: Bloomsbury Academic.

Lowenthal,D. (1994) “Identity, heritage, and history", in J.R. Gillis (ed.), Commemorations: The Politics of National Identity, Princeton, NJ: Princeton University Press, 41-60.

Mannur, A. (2007) "Culinary nostalgia: authenticity, nationalism, and diaspora", Melus 32(4): 11-31.

Mason, L. (2004) "Inghilterra", in M. Montanari and F. Sabban (eds), Storia e geografia dell'alimentazione, vol. 2, Turin: Utet, 826-40.

McKinley, L. (2010) Yes to Polenta, No to Couscous!: Constructed Identities and Contested Boundaries between Local and Global in Northern Italy's Gastronomic Landscape, Henry M. Jackson School of International Studies Departmental Honors Thesis.

Mennell, S. (1985) All Manners of Food: Eating and Taste in England and France from the Middle Ages to the Present, Oxford: Basil Blackwell.

Metro-Roland, M.M. (2013) "Goulash nationalism: the culinary identity of a nation", Journal of Heritage Tourism 8:2-3, 172-81.

Mihăilescu,V. (2012) “Ulysse ou le balkanisme heureux”, Civilisations 60(2): 13-22.

Mintz, S. (1985) Sweetness and Power: The Place of Sugar in Modern History, New York: Viking.

Mintz, S. (2008) "Food and diaspora”, Food, Culture and Society 11(4): 509-23. 
Mintz, S. and Friedmann, H. (2004) "Colonialismo e prima mondializzazione", in M. Montanari and F. Sabban (eds), Storia e geografia dell'alimentazione, vol. 1, Turin: Utet, 421-38.

Möhring, M. (2012) Fremdes Essen: Die Geschichte der ausländischen Gastronomie in der Bundesrepublik Deutschland, Berlin: Walter de Gruyter.

Montanari, M. (2013) Italian Identity in the Kitchen, or Food and the Nation, New York: Columbia University Press.

Montanari, M. and Capatti, A. (2003) Italian Cuisine. A Cultural History, New York: Columbia University Press.

Narvselius, E. (2015) "Spicing up memories and serving nostalgias: thematic restaurants and transnational memories in east-central European borderland cities", Journal of Contemporary European Studies 23(3): 417-32.

Neuman, N. (2017) "An imagined culinary community: stories of morality and masculinity in 'Sweden - the new culinary nation"', Scandinavian Journal of Hospitality and Tourism 18: 149-62.

Neuman, N. and Fjellström, C. (2014) "Gendered and gendering practices of food and cooking: an inquiry into authorisation, legitimisation and androcentric dividends in three social fields", NORMA: International Journal for Masculinity Studies 9: 269-85.

Neuman, N. and Leer, J. (2018) "Nordic cuisine but national identities", Anthropology of Food 13. http://journals.openedition.org/aof/8723

Nora, P. (1989) "Between memory and history, Les Lieux de Mémoire", Representations 26: 7-24.

Ohnuki-Tierney, E. (1993) Rice as Self: Japanese Identities through Time, Princeton, NJ: Princeton University Press.

Omar, S., Karim, S., Bakar, A. and Omar, S.N. (2015) "Safeguarding Malaysian heritage food (MHF): the impact of Malaysian food culture and tourists' food culture involvement on intentional loyalty", Procedia-Social and Behavioral Sciences 172: 611-18.

Ory, P. (1992) "La gastronomie", in P. Nora (ed.), Les lieux de mémoire, vol. 3.2, Paris: Gallimard, 823-53.

Osterhammel J. (2014) The Transformation of the World: A Global History of the Nineteenth Century, Princeton, NJ: Princeton University Press.

Ott, C. (2011) Feinschmecker und Bücherfresser: Esskultur und literarische Einverleibung als Mythen der Moderne, Paderborn: Fink.

Parasecoli, F. (2017) Knowing Where It Comes From. Labelling Traditional Foods to Compete in Global Markets, Iowa City: University of Iowa Press.

Parkhurst Ferguson, P. (2004) Accounting for Taste: The Triumph of French Cuisine, Chicago: University of Chicago Press.

Parkhurst Ferguson, P. (2010) "Culinary nationalism”, Gastronomica 10(1):102-9.

Pérez Samper, M.d.1.Á (2012) "Lo scambio Colombiano e l'Euoropa”, in M. Montanari and F. Sabban (eds), Storia e geografia dell'alimentazione, vol. 1, Turin: Utet, 351-76.

Pilcher, J.M. (2012) "Cultural histories of food", in J.M. Pilcher (ed.), The Oxford Handbook of Food History, New York: Oxford University Press, 42-60.

Porciani, I. (2002) "Famiglia e nazione nel lungo Ottocento", in P. Ginsborg and I. Porciani (eds), Famiglia Stato Società civile special issue, Passato e presente 57, 11-39.

Porciani, I. (2008) "Weaving the nation together. Women's traditional needlework as a rhetorical tool in national and regional discourse", in Y.Yannitsiotis, D. Lambropolou, and C. Salvaterra (eds), Rhetorics of Work, Pisa: Plus, 27-44. 
Porciani, I. (2018) “Cibo come patrimonio. Un'introduzione”, Storicamente 14(1). doi: 10.12977/stor691

Poulot, D. (1997) Musée, nation, patrimoine, 1789-1815, Paris: Gallimard.

Poulot, D. (2015) “Introduction”, in D. Poulot (ed.), Représentations et alimentation: arts et pratiques alimentaires (138 ${ }^{\mathrm{e}}$ Congrès national des sociétés historiques et scientifiques, Rennes, 2013), Paris: Éditions du CTHS, pp. 5-9.

Pujol, A. (2009) “Cosmopolitan taste”, Food, Culture \& Society 12(4): 437-55.

Ramli, A.M., Zahari, M., Ishahk, N. and Sharif, M. (2013) "Food heritage and nation food identity formation", Hospitality and Tourism: Synergizing Creativity and Innovation in Research 407: 162-8.

Ranta, R. (2015) "Food and nationalism: from foie gras to hummus", World Policy Journal. https://worldpolicy.org/2015/09/08/food-nationalism-from-foie-gras-to-hummus/

Raviv,Y. (2003) "Falafel: a national icon", Gastronomica 3(3): 20-5.

Régnier, F. (2005) "Le monde au bout des fourchettes: voyage dans l'exotisme culinaire". www.lemangeur-ocha.com/wp-content/uploads/2012/04/Regnier_ Exotisme_culinaire3.pdf

Renko, S. and Bucar, K. (2014) "Sensing nostalgia through traditional food: an insight from Croatia", British Food Journal 116(11): 1672-91.

Riera i Melis, A. (2004) "Spagna”, in M. Montanari and F. Sabban (eds), Storia e geografia dell'alimentazione, vol. 2, Turin: Utet, 757-81.

Rockower, P. (2012) “Recipes for gastrodiplomacy”, Place Branding and Public Diplomacy, 8(3): 235-46.

Roden, C. (1974) Book of Middle Eastern Food, New York: Vintage Books.

Rogers, B. (2004) Beef and Liberty: Roast Beef, John Bull and the English Nation, New York: Chatto \& Windus.

Roux, J.V. (2017) La table: une affaire d'Etat, Paris: Les éditions du Cerf.

Rowley, A. (2006) Une histoire mondiale de la table. Stratégies de bouche, Paris: Jacob.

Rowley, A. (ed.) (1997) Les français à table. Atlas historique de la gastronomie française, Paris: Hachette.

Roy, P. (2002) "Reading communities and culinary communities: the gastropoetics of the South Asian diaspora", Positions: East Asia Cultures Critique 10(2): 471-502.

Saillard, D. (2010) "Nourritures et territoires en Europe. La gastronomie comme frontière culturelle", Eurolimes, Journal of the Institute for Euroregional Studies 9: 127-39.

Saillard, D. (2014) La Cuisine de l'Autre. Échanges et rivalités dans les relation s gastronomiques franco-anglaises du XVIIIe siècle à nos jours. https://hal.univ-lorraine.fr/hal-01484026

Scarpellini, E. (2016) "Il cibo come cultura italiana nel mondo: dall'emigrazione alla globalizzazione”, Memoria e Ricerca 24(2): 193-208.

Scholliers, P. (ed.) (2001) Food, Drink and Identity: Cooking, Eating and Drinking in Europe since the Middle Ages, New York: Berg, 3-22.

Scholliers, P. and Teughels, N. (2015) A Taste of Progress: Food at International and World Exhibitions in the Nineteenth and Twentieth Centuries, Farnham: Ashgate.

Selenis, V. (2010) "Lithuania", in I. Porciani and L. Raphael (eds), Atlas of European Historiography, Basingstoke: Palgrave Macmillan, 83-5.

Sengupta, J. (2010) "Nation on a platter: the culture and politics of food and cuisine in colonial Bengal”, Modern Asian Studies 44(1): 81-98.

Shields, J. (2014) "Le Front National: From Systematic Opposition to Systematic Disintegration?”, Modern E Contemporary France 22(4): 491-511. 
Sims, R. (2009) "Food, place and authenticity: local food and the sustainable tourism experience", Journal of Sustainable Tourism 17(3): 321-36.

Smith,A.K. (2009) "National cuisine and nationalist politics: V. F. Odoevskii and 'Doctor Puf', 1844-45", Kritika: Explorations in Russian and Eurasian History 10(2), 239-60.

Smith, A.K. (2012) "National cuisines", in J.M. Pilcher (ed.), The Oxford Handbook of Food History, New York: Oxford University Press, 444-60.

Smith, L. (2006) Uses of Heritage, London: Routledge.

Spang, R. (2000) The Invention of the Restaurant: Paris and Modern Gastronomic Culture, Cambridge, MA: Harvard University Press.

Storm, E. (2016) "The nationalisation of the domestic sphere", Nations and Nationalisms 23(1): 173-93.

Taguieff, P.A. (2015) La revanche du nationalisme: Néopopulistes et xénophobes à l'assaut de l'Europe, Paris: Presses universitaires de France.

Tellström, R., Gustafson, I. and Lindgren, H. (2008) "Constructed national food and meal archetypes at international exhibitions from Paris 1867 to Aichi 2005”, National Identities 10(3): 313-27.

Tholstrup Hermansen, M.E. (2012) "Creating terroir: an anthropological perspective on New Nordic Cuisine as an expression of Nordic identity", Anthropology of Food 7: 7249 .

Timothy, D. (2016) Heritage Cuisines: Traditions, Identities and Tourism, London-New York: Routledge.

Toaff, A. (2004) "Culture ebraiche nel mondo", in M. Montanari and F. Sabban (eds), Storia e geografia dell'alimentazione, vol. 2, Turin: Utet, 272-85.

Tornatore, J.L. (2012) "Anthropology's payback: the gastronomic meal of the French, the ethnographic elements of a heritage distinction", in R. Bendix, A. Eggert and A. Peselmann (eds), Heritage Regimes and the State, Göttingen: Universitätsverlag Göttingen, 341-65.

Ubertazzi, B. (2015) "The territorial condition for the inscription of elements on the UNESCO lists of Intangible Cultural Heritage", in N. Adell, R. Bendix, C. Bortolotto and M. Tauschek (eds), Between Imagined Communities and Communities of Practice Participation, Territory and the Making of Heritage, Universitätsverlag Göttingen: Göttingen, 111-22.

Vester, K. (2015) A Taste of Power: Food and American Identities, Berkeley-Los AngelesWashington: University of California Press.

Watts, S. (2012) "Food and the Annales School", in J.M. Pilcher (ed.), The Oxford Handbook of Food History, New York: Oxford University Press, 3-17.

Welz, G. (2013) “Contested origins”, Food, Culture \& Society 16(2): 265-79.

Whitehead, C., Bozoğlu G. and Daugbjerg, M. (2019) "Remapping European heritage and memory: positions, inspirations, approaches", in C. Whitehead, S. Eckersley, M. Daugbjerg and G. Bozoğlu (eds), Dimensions of Heritage and Memory: Multiple Europes and the Politics of Crisis, London: Routledge.

Wincott, A. (2015) "Heritage in danger or mission accomplished?" Food, Culture \& Society 18(4): 569-88. 